\title{
VET TEACHERS IN SLOVAKIA AND CHALLENGES FOR THEIR COMPETENCES IMPROVEMENT
}

\section{aIÍMEA ŠEBEN ZAŤKOVÁ, ${ }^{\mathrm{b}}$ MARIÁN AMBROZY}

Slovak University of Agriculture in Nitra, Faculty of Economics and Management, Tr. A. Hlinku 2, Nitra, 949 01, Slovakia College of International Business ISM Slovakia in Prešov, Duchnovičovo námestie 1, Prešov, 080 01, Slovakia email: ${ }^{a}$ tsebenzatkova@gmail.com, ${ }^{b}$ ambrozy.marian@gmail.com

This paper was supported by the Slovak grant agency KEGA under grant KEGA033SPU-4/2019 Innovative concept of curriculum and methodological "eand by the institutional grant of ISM in Prešov under grant IG-KSV-01/2020-12-33/IP.

Abstract: The common problem of the many countries that's identified by many perticts many policy makers, educators, economists and other professionals is the problem of high level of youth unemployment rate. Properly prepared workforce for the European economy are cures the update vocational education teaching (further VET) - teachers qualifications and competences is very urgent in the all countries of EU. This study deals with teacher preparation in Slovakia and concisely describes selected results of questionnaire survey on vocational education teacher competences. The study provides an introduction to the theme of teacher competence improvement through small survey conducted at Slovak university of Agriculture in Nitra and suggests some challenges for solution in VET teachers preparation. There is a need of innovative practical approach to stimulating and develop key competences among students in VET institutions. This need is also connected with the quality of VET teachers and the professional teacher competences development in teachers' preparation and in their further education.

Keywords: VET teachers, key competences, teacher competences, educational system in Slovakia; teacher preparation

\section{Introduction}

The European social and political agenda recently prefers vocational training as an important tool for the sustainable development. Competence demands, combined with a high-level skilled workforce, are a challenge for the teaching community. It is possible to state their increasing tendency. The eventuality of success expects the necessary competencies.

Today, many European countries indicate high unemployment rates among young people. Slovakia is a very open economy with total annual export and import over $200 \%$ of GDP. Since its independence Slovakia has been all the time characterized by a powerful share of employed in industry, regardless changes in other sectors, e.g. growth within the service sector and dramatic decrease of employed people in agriculture (from 256,489 as of 31st December 1992 to 84,900 in 2009 (LFS), according to the Statistical Office SR). According to the Labor Force Sample Survey published in 2020, „2,59 million Slovaks were employed within the domestic economy and abroad in the 3rd quarter of 2019 and also the employment rate reached 73,4 \%. The highest rate of unemployed in Slovakia is still among the youngest people. Due to the corona crisis we can expect its growth again. In the first quarter of 2020 was the youth unemployment rate $25,5 \%$ among people aged 15-24“ (according to statistical office of SR).

Even a decade ago, unemployment rates were higher. ISCED 3-4 educated people aged $20-24$ reached $30.6 \%$ unemployment. It was the sixth place in the EU. Young and old people perceive their unemployment worse because they perceive their employability more difficult than middle-aged people. The economic crisis, which took place 10 years ago, also deprived middle-aged people of their jobs. At the moment, we can talk about the corona crisis, which potentially increases the unemployment rate.

There are significant changes in economic fluctuations, due to covid, as well as political instability, rapid technological progress and the need for new competencies in connection with the development of IT technologies. For VET education, this means new challenges associated with sustainable economic development.
In EU conditions "there are offered different policies and supportive financial programs both by national and EU bodies" (Kotyza. Tomšík 2014). The very important task of the contemporary education is to develop and increase the competences of the employees, to maintain internationally competitive research and development basis and to improve the application of knowledge for the highest benefit of the whole society (Kuna, Hodal, Hašková 2019).

Dramatic economic, technological and societal changes within the different parts of the world are arising a new significant role of VET in sustainable world development. "Internationally, vocational education and training (VET) is intended to fulfil important economic and social objectives” (Schmidt 2020: 276). On the contrary, there also are many questions arising on quality of VET preparation. As an example, in England are still persistent ,the chronic difficulties in recruiting teachers of vocational science, engineering and technology (SET) to FE colleges“ (Hanley, Orr 2019: 103). This is often not the unique problem of one country, but the similar situation is also seen across the all European countries. Lack of quality VET teachers may be a modern phenomenon. Quality education, is more and more important for all countries because it is one of the crucial factors influencing their economic competitiveness in the globally connected knowledge-based economies. „Just as there is great diversity among the students at VET, the students in the teacher training courses differ considerably in terms of educational backgrounds and work experiences, and particularly in terms of their teaching contexts“ (Duch, Andreasen 2017: 290). Above mentioned differences are also connected to the to the obtained level of education of the graduates. „European Credit System for Vocational Education and Training is an initiative promoted at European level, designed as a technical framework for the transfer, recognition and, where appropriate, accumulation of learning outcomes by learners in VET, thereby promoting transnational mobility and access to lifelong learning“ (de Paor 2018: 1). There are increasing demands on permanent changes in vocational education and in our opinion they will further raise. Growing struggle between education providers and the society demands will continue. „Seeking prime quality vocational education and training and better education, the teaching staff design and apply different educational technologies, which are supported by the research paradigms of the quality of training and studies“ (Gedviliené, Tútlys, Daukilas 2019: 256). For example, the reasearch of Friedrich and Hirtz shows, that in Germany graduates of combined VET education and high school diploma achieve a higher wage rating (Friedrich, Hirtz 2021). Schuster and Margarian add, that in noncompetitive peripheral labor markets, graduates with a high school diploma are more likely to enter VET education (Schuster, Margarian 2021).

VET provides opportunities also for internationalisation. Gao states, that there are significan differences in the primary motivation for initiation of international cooperation among VET teachers. While one group preferes activities on the basis of evidently commercial approach, other group of teachers preferes more instrumental and developmental character (Gao 2020: 232). Such results are helpful to identify the motives for international cooperation in the field of VET education.

The nature of VET teacher training practices requires innovations in their preparation and training. Cooperation with students is influenced by the quality and attention paid to their own teaching. It is an integral part of professional development. There is a wide range of models that can be and are used in vocational education. According to UN recommendations, VET teachers should have a position identical to other teachers. For example, a structured survey among Italian and Lithuanian teachers revealed some problems: "the marginalisation of the VET teacher's work and working conditions, especially the 
dissatisfying wages and poor career opportunities, and the absent or weak institutionalisation of the VET teacher's qualifications and training” (Tacconi et al. 2020).

\section{Teachers and trainers in Slovakia and their training}

"In the ever-changing environment of vocational education and training (VET), an individual teacher can create a learning environment which can inhibit or promote the success of a student" (Dutschke, 2018: 163). All over the world exist different models and ways to obtain VET teacher qualifications. Access to the teachers' qualification is typically regulated by and is also subject to the control of a ministerial authority. In the almost all European countries, to be qualified as a teacher in vocational training, it is necessary to have a higher education degree followed by teacher training controlled at national level. In some cases, the higher education degree can be substituted by a nationally recognized vocational qualification. In most countries the qualifications mandatory for trainers or workplace instructors have not been formally defined. Neither do there appear to be any specific training paths to become a trainer of continuing training in a company or in a training organization (Cort, Härkönen, Volmari 2004). Teachers are usually in contrast with workplace trainers and instructors. Despite the fact that national regulations force (varying) requirements on staff involved in initial vocational training, there are no formal requests for the qualifications or formal training required to take part in continuing training. This contradictory situation can be observed also in Slovakia.

VET staff is predominantly bound to the educational institutions. There can be divided traditionally three groups of VET school teachers according to the education legislation: 1 . teachers of general subjects; 2 . teachers of vocational subjects; 3 . teachers of practical training (Khonamri, Azizi, Králik, 2020). Teachers of practical training are responsible for assisting students in developing their skills throughout the practical - primarily manual training. Even though VET in Slovakia is dominantly school-based, there exist the possibility to carry out practical training also outside the school. Built on a school and a company agreement, practical training can be provided straight by the company in its own premises and by its own staff, but what is important this is under the supervision of the school. These professional staff of the company are called instructors to distinguish between them and trainers from schools. Since the year 2015 exists in Slovakia possibility of "Dual education". Dual education is a system of vocational education and training through which student acquires the knowledge, skills and competences necessary for the profession. It is characterized especially by a near connection between general and vocational theoretical education in secondary vocational school with practical training at a specific employer.

VET teachers preparation is actually organized according to the Act no. 138/2019 Coll. on pedagogical and professional staff. According to this Act, there are four stages of career development, ascending from a beginner to an independent teacher, a teacher with the first attestation and the last stage is a teacher with the second attestation. According to the law there exist also several forms of professional development in teacher further education: innovative, functional, qualification and extending education.

The follow-up of knowledge acquired during theoretical preparation in connection with the practical implementation of acquired knowledge directly in the specific conditions of the secondary school teaching process becomes especially important in the process of higher education teacher preparation. By participating in educational practice, students - future teachers gain and subsequently develop, the experience, skills and competences necessary for the practice of the teaching profession. During the educational practice as the part of teacher preparation and training, student also experiences the positives and negatives arising from the teaching profession and, on the basis of regular pedagogical practice, also acquires the necessary self-confidence for passing on knowledge to generations of students at secondary schools (Michvocíková, Sirotová 2019).

\section{Increasing of teacher competences}

According to the above mentioned it can be stated that study courses for students should be also focused on presenting additional skills and competences for their future life and profession related to the fields they have chosen. „There are many various discussions about key competencies, professional competencies in education and even the teacher professional competencies“ (Gadušová, Hašková 2015). For example, Kyriacou (1996) identifies as essential teaching skills and competences the following: Planning and preparation; Lesson presentation; Lesson management; Classroom climate; Discipline; Assessing pupils' progress; Reflecting and evaluation. Competence profile of high school teacher - teaching professional (vocational) subjects in Slovakia according to professional standards for individual categories and subcategories of teaching staff (Pokyn ministra č. 39/2017) is defined as follows:

Table 1. Competence profile of high school teacher - teaching professional (vocational) subjects

\begin{tabular}{|c|c|c|c|}
\hline \multicolumn{2}{|r|}{ Areas } & \multicolumn{2}{|r|}{ Competences } \\
\hline 1. & Student & $\begin{array}{l}1.3 \\
1.4\end{array}$ & $\begin{array}{l}\text { To identify the developmental and } \\
\text { individual characteristics of the } \\
\text { student } \\
\text { To identify psychological and social } \\
\text { factors of student learning } \\
\text { To identify the sociocultural context } \\
\text { of student development }\end{array}$ \\
\hline 2. & Educational process & $\begin{array}{l}2.1 \\
2.2 \\
2.3 \\
2.4\end{array}$ & $\begin{array}{l}\text { To master the content and didactics of } \\
\text { subjects } \\
\text { Plan and design lessons } \\
\text { Implement teaching } \\
\text { Evaluate the course and results of } \\
\text { teaching and students learning }\end{array}$ \\
\hline 3. & $\begin{array}{l}\text { Professional } \\
\text { development }\end{array}$ & & $\begin{array}{l}\text { Plan and implement own professional } \\
\text { growth and self-development } \\
\text { Identify with the professional role } \\
\text { and school }\end{array}$ \\
\hline
\end{tabular}

Source: Pokyn ministra č. 39/2017

To reach quality education it is needed also to focus on teacher development. Authors Cort \& Härkönen \& Volmari (2004) point to some of the skills and knowledge teachers need to acquire and that teacher training should provide. These include:

- „new pedagogical skills and competences in line with the learner centered approach of modern pedagogical theory ('pedagogical update') and on-the-job learning techniques now being offered to trainees;

- up-to-date 'vocational' skills related to modern technologies and work practices ('vocational update');

- $\quad$ awareness of the needs of business and employers;

- $\quad$ skills for team work and networking;

- managerial, organizational and communication skills“.

\subsection{Results of small survey on teacher competences}

In connection to the previously indicated areas connected with the vocational education and the teacher competences improvement, this study is complemented with the results of qualitative research that's aim was trying to monitor the situation of competence development in educational practices. A review and examination of related documents and a qualitative methodology were employed. In the study are also summarized results of a questionnaires from the VET teachers and students.

Surveyed were several categories of the qualitative research including the following theoretical groups:

- valuation of VET teacher competences by studentsteachers,

- valuation of development of key competences of students by VET teachers. 
Survey was conducted in 2020 within a research sample of 83 students of Complementary pedagogical study at SUA in Nitra. SUA is the unique institution in Slovakia preparing teachers for agri-food sector. The aim of the survey was to evaluate the level of their own competence development. The sample consisted of two groups of $1^{\text {st }}$ and $2^{\text {nd }}$ year students. They were asked to choose from the list of nine groups of competences (inspired by Kyriacou and professional standards) to assess their least developed competence.

Second part of the survey was based on answers of VET teachers from 5 secondary vocational schools in Nitra city (vocational schools preparing professionals for agriculture, food industry, economical sector and technical fields of study). Teachers were asked to list the competences they primarily develop among their students and to suggest the proposals for their improvement (open question).

A) Self-assesment of future teachers' competence development

Which teaching competencies do you rate as the least developed so far?

$1^{\text {st }}$ year students' results (46 answers) in order of answers frequency:

1. Work with students with special needs;

2. Maintaining classroom discipline;

2. Realization of lessons and Language and

3. communication skills;

4. Assessment of student achievement and Reflection and selfevaluation;

5. Lesson planning and preparation and Influencing classroom climate;

Knowledge and erudition in the field of study- nobody indicated as the least developed competence. Two answers were as follows: "Since I don't teach I can't judge”.

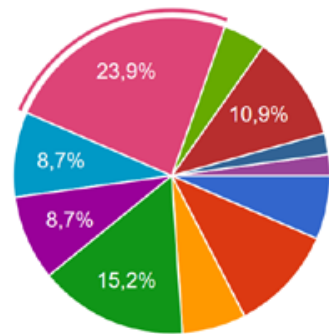

Figure 1. $1^{\text {st }}$ year student teachers least developed competences

$2^{\text {nd }}$ year students' results (37 answers) in order of frequency of answers:

1. Work with students with special needs;

2. Influencing classroom climate;

3. Lesson planning and preparation and Reflection and selfevaluation;

4. Assessment of student achievement and Knowledge and erudition in the field of my study;

5. Maintaining classroom discipline and Realization of lessons;“

The option "Language and communication skills" nobody indicated as the least developed competence. However, lacks of the competence development perceived by students in $2^{\text {nd }}$ year of their study can be expressed by the following quotations as an example: ( $\mathrm{S}=$ student):

S1: Right now all of them, because I haven't taught "real" yet, unless I count the few hours of teaching practice during the study.
S2: Difficult to answer ... apart from the practice lessons I did not teach, so developed is a strong word ... I have a lot of work to do once I have to teach.

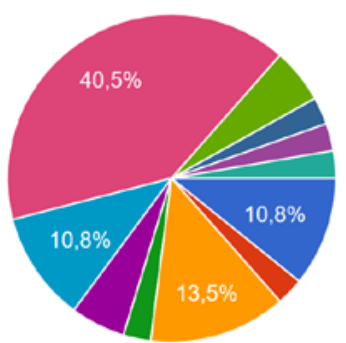

Figure 2. $2^{\text {nd }}$ year student teachers least developed competences

B) Competences developed by teachers in secondary vocational education

Qualitative Analyses of results from questionnaires:

Teachers according to their answers the most often devote their attention to development of the following competences and skills of their students in VET:

- problem solving, ICT skills, communicative and social competences, soft skills,

- work with literature,

- entrepreneurial competences through examples and implementation of students' own innovative ideas, selfrealization, self-knowledge, self-development, active involvement for future entrepreneurial activity in a professional career,

- $\quad$ soft skills and financial literacy.

Selected proposals of teachers for improving the development of competences in vocational education $(\mathrm{T}=$ teacher$)$ :

T1: To improve the equipment of the schools or equipment of ICT classrooms.

T2: Work with the Internet to a greater extent. T3: Many vocational study programs are based on dual education - there are big differences between theory and practice, it would be good to minimize them. T4: To develop and promote pupils' independence and financial literacy.

T5: In addition to traditional hard skills development, it is necessary to develop soft skills, especially to develop communication and work with people.

\section{Pedagogical and vocational skills; pedagogical and vocational update as challenges}

Qualified VET students, and professionals, meet and compete in skills competitions (Andersson, Köpsén, 2019). Teachers and trainers in VET are required to possess two distinctive groups of skills:

1. Pedagogical skills - skills and abilities or so called pedagogical competence involves activities eg. to plan, organize, teach and instruct and to be able to assess the outcomes of the teaching. These are the basic skills of all teachers regardless of the field or subject they teach.

2. Expert knowledge and vocational skills are the basis for VET teachers to exchange their expertise to trainees so they are able to perform gained vocational skills after leaving school and start their jobs - this is a demand to have a stable ground in the theory that leads to these skills development.

Earlier, teachers attained pedagogical and vocational skills during their studies at the beginning of their professional path. 
Currently this is not sufficient because the national VET systems are changing continuously. Educational research and theory constantly proposes new teaching approaches, strategies, innovative methods and techniques, the use of the latest modern technology. Also the workplace and the needs of labor market are in a rapid change.

In such new circumstances, it is fundamental that teachers constantly bring up-to-date their skills. Cort, Härkönen and Volmari (2004) talk about these procedures as pedagogical update and vocational update.

Among the new challenges for teacher training could be included new target groups, changing pedagogical paradigms, ICT developments, labor market developments or increasing internationalization:

Target groups in VET are more varied than before. „The age at which young people leave education for the labour market has increased in recent decades, and entering upper secondary education has become the norm“ (Eirikíksdóttir, Rosvall 2019: 355). For example there is a rising number of adults attending VET programs and teachers have to deal with their various skills, attitudes, motivations, which often differ to those of youth. VET teachers have to look for new teaching methods with regard to the previous experience of their learners, to the needs of the specific group of students.

Changes in educational theory now focuses more on learning rather than 'transmitting' information by teachers. Therefor optimum teaching requires teachers to use a wide range of activating teaching methods, containing in example: projects, group work, problem solving, discussions, case studies, etc. "Social entrepreneurs and change agents trained in the university (and not just the business school) mitigate sustainable development problems” (García-Gonzáles, Ramírez-Montoya 2021). Selected studies bring also some interesting results and on their basis can be implemented some improvements in the educational practice. For example, Karpáti-Daróczi and Karlovitz identified, that Albanian students have in comparison with students in Hungary higher contact with entrepreneurial environment. On the other side, Hungarian students prove more entrepreneurial personality traits (Karpáti-Daróczi, Karlovitz 2020: 47). Some significant changes in the area of stability of interests in vocational education and training were also identified (Etzel, Nagy 2021). As these findings show, it is important to use much more activating teaching methods and experience based teaching and learning in VET according to the demands of the particular national educational systems.

Among the recent technological developments belongs development of ICT which entered also the educational process. Currently all VET systems call for general skills development in ICT. All graduates entering the labor market are required to use ICT in their future jobs, but on the other hand teachers themselves are forced to use ICT as a teaching tool, as well as for administration (Kuna, Hodal, Hašková 2019).

Due to the labor market development teachers are required to equip students with the up-to-date skills important in their future careers. On the other hand, those skills are in permanent change. One of the demanding challenges is how to keep up to date vocational skills of teachers so they can provide graduates with the skill the labor market requires. The best model of lifelong learning cannot be attained without expert teachers. This is an important task for government and professional organizations. Baglama and Uzumbolyu recommend as an effective measure: „career counselling interventions ought to be increased during high school in order to increase career decision-making selfefficacy and vocational outcome expectations“ (Baglama, Uzunboylu 2017: 8). Other possibilities advise Tomšíková, Hudečková and Tomšík, who recommend ,greater interconnection of specific teaching subject with practice or closer cooperation of actors at local level, which have a potential to enhance an attractiveness of secondary education“ (Tomšíková, Hudečková, Tomšík 2019: 143).

Another great challenge is internationalising VET teacher skills. As Khonamri, Azizi and Králik (2020) state „market developments imply that to an increasing extent national VET systems are called upon to implement an international dimension in the provided training. Similarly, the action programs promoted by the EU Commission carry this dimension into the classroom. For teachers, parts of serious importance are including language skills, knowledge of other countries, knowledge of trades and trade requirements in other countries, intercultural communicative skills, etc" (Khonamri, Azizi, Králik 2020).

In accordance with Rybanská (2020) it can be concluded that wider access to education is an opportunity for schools to benefit from an increasingly diverse individual experience. In response to diversity and growing expectations of education is essential a shift in its provision, through a student-centered approach to learning and teaching, the acquisition of flexible learning pathways and the recognition of competences acquired outside the official curriculum. The schools themselves are also increasingly differentiated in terms of their mission, the way in which education and cooperation are provided, including the rise of internationalization, digital learning and new forms of education provision.

Internationalization of VET teachers' skills and competencies is the key for maintaining the graduates' competitiveness at the labor markets.

It should be in the center of the educational policy that the particular countries implement the international dimension in the pedagogical preparation for the teaching of vocational subjects. These skills and competences are also supported by the EU Commission through action programs. The competences we consider to be the key in the field of VET teacher preparation are for example realities about other countries, knowledge of foreign languages, knowledge of the business protocol of other cultures, knowledge of the etiquette of other nations and cultures, etc.

\section{Conclusion}

Vocational training has indeed gained a significant role in recent years in Europe. Although Slovak republic is an quite open economy and having relatively high export and import rates, but it is currently suffering from high unemployment among the younger generation. In addition, there has been a dramatic decline in employment in agriculture and other areas of industry, but increase in services in the recent decades. The vocational training system should contribute to general economic development, to adjust to the recent demands. In Slovakia, there is still a system that is set up to produce a percentage of strong secondary cadres. In addition to higher education, further professional education of adults has a significant position there. Currently it has been provided by about 300 facilities. The educational institutions are subject to the accreditation process. Problems are caused by low investment in education and low investment into research of vocational training. Content of work of the vocational teacher - trainer has been relatively fast changing. There are three categories of teacher's training. In the case of its'absence there is a possibility of passing a complementary pedagogical study. Graduate thus obtains full qualification for secondary vocational schools. Educational content should be compatible with the possibility of self-plan for lifelong learning. VET teachers need to acquire new teaching skills, up-to-date 'vocational' skills, skills for team work and networking and also managerial skills and many other. They also need to understand the role of graduates after leaving school. Since it is not possible to acquire all competences in early career, VET teachers should continuously update their professional and pedagogical skills. As can be seen also according to the results of our small survey, the students-teachers stated also some areas 
of their competences that can be still improved. For the pedagogical up date are available various forms of professional development in Slovakia. Vocational education deals with particular problems and challenges. There is especially a need to find suitable teaching methods which make use of previous experience of the educated, to absorb changes in paradigm of teaching theory, to understand the role of teacher as coach and facilitator, and to implement new teaching methods in teaching process (such as case studies, projects, workshops etc.). It is important to provide teachers with suitable pedagogical theory but on the other hand, the practice will be gained through their further teacher experience. A particular requirement is the ability to fully benefit from ICT. It is related to the ability to use elearning and blended-learning. Teachers must keep up with new technology if they want to prepare graduates who are fully applicable. The problem is the acquisition of suitable candidates for teaching positions. Challenge is in improving internationalization skills of VET teachers and providing the international dimension of education. In that context, the internationalization can be supported via action programs promoted by the EU Commission. As teacher training is constantly under pressure from economic, social, political and legislative changes and at the same time must adapt to scientific progress, the content and implementation aspects of the VET teacher preparation must respond flexibly to the current requirements of the time.

We are aware that our study is only a small survey in the field of professional competences of teachers of professional (vocational) subjects and pedagogical practices of students, but it is an important factor that can contribute to streamlining not only practical training but especially theoretical preparation of teachers. This requires constant attention in the future. Based on the above mentioned, we state that a competent teacher must really meet a large number of requirements for the performance of his profession, on which the quality and effectiveness of his pedagogical work depends.

\section{Literature:}

1. Andersson, P., Köpsén, S. (2019). VET teachers between school and working life: boundary processes enabling continuing professional development, Journal of Education and Work, 32(6-7), pp. 537-551. ISSN 2411-3123, DOI: 10.1080/1363908 0.2019 .1673888

2. Baglama, B., Uzunboylu, H. (2017). The relationship between career decision-making self-efficacy and vocational outcome expectations of preservice special education teachers, South African Journal of Education, 37(4), ISSN 2076-3433, DOI: 10.15700/saje.v37n4a1520

3. Borisova, O. V., et al. (2016). Problems of using innovative teaching methods for distance learning students. Mathematics Education, 11(5), pp. 1175-1184, ISSN 1306-3030.

4. CEDEFOP. (2012). Slovakia VET in Europe - Country Report 2012. Retrieved from: http://libserver.cedefop.europa .eu/vetelib/2012/2012_CR_SK.pdf

5. Cort, P., Härkönen A., Volmari K., (2004). PROFF Professionalisation of VET teachers for the future. ( $1^{\text {st }}$ ed.) Luxembourg: Office for Official Publications of the European Communities. Cedefop., p. 68, ISBN 92-896-0327-5.

6. de Paor, C. (2018). Supporting change in VET: teachers' professional development and ECVET learner mobility. Empirical Research in Vocational Education and Training, 10(1), ISSN 1877-6337, DOI: 10.1186/s40461-017-0062-3

7. Duch, H., Andreasen, K. E., (2017). VET again: Now as a VET teacher. International Journal for Research in Vocational Education and Training, 4(3), pp. 289-305. ISSN 2197-8638, DOI: 10.13152/IJRVET.4.3.6

8. Dutschke, A. (2018). Understanding VET teacher attitudes to student support in a major public VET provider. International Journal of Training Research, 16(2), pp. 163-181. ISSN 14480220, DOI: 10.1080/14480220.2018.1461674

9. Eirikíksdóttir, E., Rosvall, P. A. (2019). VET Teachers' Interpretations of Individualisation and Teaching of Skills and Scial Order in two Nordic Countries. European Educational
Research Journal, 18(3), pp. 355-375, ISSN 1474-9041, DOI: 10.1177/1474904119830022

10. Etzel, J. M., Nagy, G. (2021). Stability and change in vocational interest profiles and interest congruence over the course of vocational education and training. European Journal of Personality 35(4), pp. 534-556, ISSN 0890-2070, DOI: 10.1177/08902070211014015

11. Friedrich, A., Hirtz, S., 2021. Occupation-specific wage returns: shedding light on differentials between employees with a VET degree either with or without an Abitur. Empirical Research in Vocational Education and Training 13(1), ISSN 1877-6337, DOI: 10.1186/s40461-021-00111-5

12. Gadušová, Z., Hašková, A. (2015). Training Educational Staff: Vision and Reality in Pre-service and In-service Training. EDULEARN 15 Proceedings. Seville: IATED Academy, pp. 2046 - 2053, ISBN 978-84-606-8243-1.

13. Gao, Y. (2020). International Collaborations in the VET Sector: Motivations and Challenges. Journal of Studies in International Education 24(2), pp. 232-248, ISSN 1028-3153, DOI: $10.1177 / 1028315319835531$

14. Garcia-Gonzales, A., Ramirez-Montoya, M. S. (2021). Social entrepreneurship education: changemaker training at the university. Higher Education, Skills, and Work-based Learning (article in press), ISSN 2042-3896, DOI: 10.1108/HESWBL-012021-0009

15. Gedviliené G., Tútlys, V., Daukilas, S., (2019). The role of the key competences of VET teachers in enhancing the quality of the teaching process. New Educational Review, 56(2), pp. 255270, ISSN 1732-6729, DOI: 10.15804/tner.2019.56.2.21

16. Hanley, P. Orr, K. (2019). The recruitment of VET teachers and the failure of policy in England's further education sector. Journal of Education and Work, 32(2), pp. 103-114, ISSN 13639080, DOI: 10.1080/13639080.2019.1617842

17. Kárpáti-Daróczi. J., Karlovitz, J. T. (2020). Comparative Analyse of Entrepreneurial Competences between Albanian and Hungarian Students. Multidisziplináris Kihivások, Sokszinü Válaszok 1, pp. 45-60, ISSN 2630-886X.

18. Khonamri, F., Azizi, M., Kralik, R. (2020). Using interactive e-based flipped learning to enhance EFL literature students' critical reading. Science for Education Today, 10(1), pp. 25-42, ISSN 2658-6762, DOI: 10.15293/2658-6762.2001.02

19. Kotyza, P., Tomšík, K. (2014). Effects of Public Support on Producer Groups Establishment in the Czech Republic and Slovakia. Economics and Informatics, 6(2), pp. 37-47, ISSN 1804-1930.

20. Kuna, P., Hodal, P., Hašková, A. (2019). Assessment of the employee education: Case study aimed at industrial production practice. ICERI2019 Proceedings, pp. 3006-3010. Seville: IATED Academy, ISBN 978-84-09-14755-7.

21. Kyriacou, Ch. (1996). Klíčové dovednosti učitele. (1st ed.) Praha: Portál., p. 155, ISBN 80-7178-022-7.

22. Michvocíková, V., Sirotová, M. (2019). Význam pedagogickej praxe $\mathrm{v}$ pregraduálnej príprave učitel'ov slovenského jazyka a cudzích jazykov. XLinguae 1(3), pp. 228239, ISSN 1337-8384. DOI: 10.18355/XL.2019.12.03.17

23. Pokyn ministra č. 39/2017, ktorým sa vydávajú profesijné štandardy pre jednotlivé kategórie a podkategórie pedagogických zamestnancov a odborných zamestnancov škôl a školských zariadení

24. Rybanská, J. (2020). Hodnotenie kvality výučby predmetu Manažment obchodnej firmy. Vybrané otázky terciárnej edukácie na Slovenskej pol'nohospodárskej Univerzite v Nitre. pp. 604-617, ISSN 1339-7400. ISBN 978-83-8111-180-5.

25. Schmidt, T. (2020). Reformed and Reduced: Vocational Education and Structural Oppression. Power and Education 12(3), pp. 276-291, ISSN 1757-7438, DOI: $10.1177 / 17577$ 43820967027

26. Schuster, K., Margarian, A. (2021). Vocational training choice from a regional perspective. Empirical Research in Vocational Education and Training 13(1), ISSN 1877-6337, DOI: 10.1186/s40461-020-00105-9

27. Tacconi, G. et al. (2020). Development of pedagogical competencies of the vocational teachers in Italy and Lithuania: implications of competence-based VET curriculum reforms. European Journal of Training and Development (article in press). ISSN 2046-9012, DOI: 10.1108/EJTD-03-2020-0041 
28. Tomšíková, K., Hudečková, H., Tomšík, K. (2019). Enhancing attractiveness of secondary agricultural education in the Czech republic. Journal on Efficiency and Responsibility in Education and Science, 12(4), pp. 135-145, ISSN 2336-2375, DOI: 10.7160/eriesj.2019.120404

\section{Primary Paper Section: A}

Secondary Paper Section: AM, AN, AO 